\title{
Espiritualidade, ética e alteridade: de Etty Hillesum a Emmanuel Lévinas
}

\author{
Orientadora: Prof ${ }^{a}$. Maria Clara Lucchetti Bingemer
}

Pesquisador: Ronilso Pacheco da Silva

Fonte: $\mathrm{CNPq}$

\section{Introdução}

O presente texto se vale do pensamento do filósofo judeu franco-lituano Emmanuel Lévinas e sua reflexão sobre a alteridade, o reconhecimento e a responsabilidade. A partir de categorias propostas por Lévinas, o texto aborda questões como violência, criminalização e a estigmatização que acompanha sujeitos socialmente marginalizados, pobres e desassistidos em contextos de violência urbana das periferias brasileiras. Para tanto, vale-se também da experiência da curta, mas intensa, vida da jovem holandesa Etty Hillesum com sua vivência de solidariedade em um dos momentos mais obscuros do século XX. Em ambos os casos, reflexão de Lévinas e vida de Hillesum, a espiritualidade e a abertura ao transcendente é determinante como elemento formador e condicionante de construção de uma nova relação social.

\section{Objetivos}

Fomentar a reflexão sobre a ruptura ética em nossos dias, a partir dos conceitos desenvolvidos por Lévinas, com maior ênfase na violência, na responsabilidade e na "produção" de sujeitos marginalizados. Promover o debate e o questionamento da criminalização e da estigmatização como "métodos" de construção de sujeitos "sem-rostos", negligenciados socialmente. Apontar caminhos, que tem na trajetória da holandesa Etty Hillesum, em meio a sua experiência durante o Holocausto, uma referência para pensar como responsabilidade pelo outro e substituição mantêm-se como elementos indispensáveis a uma alteridade. 